\title{
Urban Planning Terminology in Albanian and Foreign Languages
}

\author{
Eva Papamihali (PHD) \\ Human Sciences Faculty, \\ Aleksander Xhuvani University, Elbasan, Albania
}

Doi: 10.2478/ajis-2018-0036

\section{Abstract}

The following article aims to introduce a scientific work undertaken with the aim of producing an Urban Planning terminology Dictionary in Albanian, accompanied by French and English. The study and exposure of urban planning terminology will be treated in two works, part of one another: *The theory platform for the analyses of linguistic problems represented by this terminology. *The draft of a dictionary with the main urban planning terminology (Albanian - French - English). To accomplish these two works, a preparatory work has been done in the first stage as it follows: 1. A great quantity of urban planning terms has been taken from this branch's literature (schoolbooks; books published by urban planners about the various urban problems; this branch's periodical magazines; urban laws throughout the years alongside with the relevant regulations; etc) what makes up the factual material. 2. The theory material has been collected and studied and it includes monographs, articles, references and other editions which have dealt with Albanian terminology problems, obviously by Albanian authors. We have also used foreign literature about terminology problems, mainly in French. On this theory and factual bases and by following the scientific criteria which have been applied to draft the terminology dictionaries (Albanian - Foreign languages) by the terminology section of the Albanian language and literature Institute, we have launched the preliminary wordy of the dictionary and partially completed its equivalent in French. While working with this dictionary, we have begun dealing with one terminology problem which is used in this branch, the one of the meaning phenomena. During this whole process, there urged the need to complete the factual material and naturally to deeply exploit the theory literature.

Keywords: terminology, lexicography, urban planning

\section{Introduction}

The modern terminology expanded in the previous century, during the 1930s, when Eugen Wüster, the father of the modern terminology completed a study which was called Internationale Sprachnormung in der Technik, besonders in der Elektrotechnik (The international normalisation of the technical language)which is nowadays considered as the first theoritical work on terminology.

According to Rondeau (1984), four schools have enabled the development of modern terminology: Vienna school, Prague school, Moscow school and Canada and Quebec school.

\subsection{Vienna School}

Vienna School is the earliest one and is completely based on the work of Wüster who was somehow even its founder. His research work laid the foundations of this school by creating the basic concept of the term, its unisense, ensuring the importance of the notions system and the right definitions for each term. Wüster's work was followed by the researchers H. Bühler, I. Dahlberg, H. Felber and G. Wersig. The terminology works of this school were focused on the standartisation of notions and terms because only in this way, a fruitful communication in technical areas would be 
guaranteed. A variety of recommendations about the principles and methods which should have guided the terminologists' work were elaborated by this school. The influence of this school's works crossed the boundaries of Austria, expanding in the largest part of European countries.

\subsection{Prague School}

Prague terminology School was developed on the grounds of functional linguistics. The aim of Czechoslovakia terminology work was the structural and functional description of speciality languages,in which the terms have a dominant role and in which the Czech and Slovak languages are reflected and protected. Even this school is guided towards normalisation, codification and standartisation of terms. Among the mostly mentioned authors of this school we can name $L$. Drozd, M. Dokulil, V. Brand, M. Roudny and R. Kocourek. Between Prague and Vienna schools there has always been and there still is an exchange of information.

\subsection{Moscow School}

The first teminology research in the so called Soviet Union, accomplished by Soviet researchers and engineers, date bach to the beginnings of 1930s. Wüster's numerous writings were an urge to them. Moscow terminology school was officially founded in 1933 by two engineers S.A. Caplygin and D.S. Lotte. They also helped in creating the Commission for the technique terminology which was later called "The committee of scientific and technical terminology of the Soviet Union Science Academy". Even this school, as well as the Vienna and Prague school, aimed the normalisation of terminology. Lotte in particular dealt important issues among which we can mention: the methods for the normalisation of technical and scientific terminology; problems related to the selection of terms and structure of terminology; the creation of systems for notions and the elaboration of exact and accurate terminology. There was a difference from the Russian school between terminology and nomenclature; according to this approach the terminology collects terms corresponding to the notions which identify the area whereas the nomenclature lists the terms corresponding to the tools used in this area.

Apart from the above mentioned researchers of this school, other popular names are: T.L. Kandelaki, V.S. Kulebakin, V.I. Siforov and A.M. Terpigorev.

\subsection{The Canadian and Quebec School}

This school is more modern than the above mentioned schools because it was created in the mid ' 70 s as a necessity to respond to the urgent terminology problems which had arosen as a consequence of bilingualism.As Rondeau mentioned (1984), the Canadian researchers have presented their studies in international articles and conferences based on the traditional theory of terminology. They habe obviously been the first to use IT tools to collect and elaborate the terms. The tendency towards translation and moemalisation are characteristics of this school. This school has prioritised the French language and has worked to conserve it as a basic language for the scientific and technical terminology.

In Albania the interest for a well organised and systematic work in the area of terminology started only after the Liberation. Work woth terminology in Albania was mainly affected by the School of Moscow because of the political relations between the countries but even the School of Vienna recognising the fact that the Albanian lingusts were very good at Russian and French. In the scientific sessions in 1952 the necessity and great importance of terminology work was emphasized. In the following years they created the basis for working to create terminology which resulted in making a series of terminology dictionaries from different areas. This methodic theoritical work and the materials made the problem of terminology occupy a particular place even in the lexicography works and other linguistic works. The attention for the place that terminology 
would occupy, for eg: in various dictionaries, explanatory or multilingual, is noticed in their introduction or the principles for their composition ${ }^{1}$. In the previous studies, important problems are discussed as: the position of terminology in the literary language ${ }^{2}$, the relation of the general language lexicon with the special lexicon ${ }^{3}$, the position of terminology in the various areas of Albanian language dictionaries and the schoolbooks ${ }^{4}$ the position of dialectic lexion in terminology ${ }^{5}$, problems of the term's semantics and the understanding phenomena ${ }^{6}$, problems of the term's formation, borrowed words and native lexicon ${ }^{7}$, the terminology of some areas as the focus of articles in various scientific activities and problems of the terminology lexicon in particular periods.

\section{Urban Planning Terminology in albanian}

A terminology area, for which tere is no relevant terminology dictionary and a particular study, seen from the tools, ways and means of terms' creation, is the area of urbanism. This article aims exactly to submitt a summary of the work in progress which is being developed to enable the creation of a urban terminology distionary and a theoritical summary in which we will analyse various linguistic problems which have found a solution on the dictionaries. In this theoritical part we will also tdeal with the phrases of this terminology elaboration aiming to standardize it. Similar studies help in solving some problems and in elaborating, creating and perfectionating the terminology systems, because in general, the state of development of the terminology system in a particular area does not meet the needs of a special contemporary communication because of the inaccuracies caused by:

a) a lack of coordination of knowledge, content of the terminology system, inaccuracy of notions and not a clear distinction among them, the presence of old notions, lack of notions"

\footnotetext{
${ }^{1}$ A. Kostallari, "Parimet themelore per hartimin e Fjalorit te gjuhes se sotme shqipe", SF, Nr. 2, 1968.

${ }^{2}$ F. Leka, "Terminologjia tekniko-shkencore dhe gjuha e sotme letrare shqipe", SF, Nr. 1, 1985; H. Pasho "Terminologjia teknike-shkencore dhe vendi i saj në shqipen standarde" (botuar në përmbledhjen e punimeve të Konferencës" Shqipja standard dhe shoqëria shqiptare sot", Tiranë 2002.

${ }^{3}$ H. Pasho, "Marëdhëniet e leksikut të përgjithshëm me terminologjinë" (botuar në përmbledhjen e punimeve të Konferencës "Gjuha letrare kombëtare dhe bota shqiptare sot", Tiranë, 2002.

${ }^{4} \mathrm{~K}$. Ashta, "Terminologjia dhe vëzhgimi i saj në leksikografinë e sotme" BSH i Institutit dyvjeçar të Shkodrës, nr. 9, 1970; H. Pasho "Zhvillimi i terminologjisë së ekonomisë dhe pasqyrimi i saj në dy fjalorët shpjegues të gjuhës shqipe", SF, Nr. 1, 1984; Th. Feka, "Vëzhgime mbi leksikun terminologjik në Fjalorin e gjuhës së sotme shqipe" (1980), SF, Nr. 2, 1986; H. Pasho, "Leksiku terminologjik në veprën mësimore didaktike të Naim Frashërit”, SF, Nr. 2, 1991; F. Leka, "Vëzhgime gjuhësore dhe leksikografike mbi termat në Fjalorin e gjuhës së sotme shqipe" (1980) (botuar në "Shkrime gjuhësore, letrare, sociale”, Tiranë, 2007.

${ }^{5}$ H. Pasho, "Leksiku dialektor në terminologjinë teknike-shkencore në gjuhën shqipe”, SF, Nr. 1-2, 1988; A. Duro, "Pasqyrimi i termave me strukturë togfjalëshi në fjalorët terminologjikë të shqipes" (Leksikografia shqipe trashëgimi dhe prespektivë), Tiranë , 2005.

${ }^{6}$ H. Pasho, "Vështrim mbi disa shfaqje të shumëkuptimësisë, sinonimisë dhe antonimisë në terminologjinë e ekonomisë në gjuhën shqipe”, SF, Nr. 3, 1986; "Zhvillime kuptimore në terminologjinë e ekonomisë në gjuhën shqipe pas Çlirimit", SF, Nr. 2, 1988; A. Duro, "Fjala term dhe struktura semantike e fjalës shqipe", SF, Nr. 3-4, 1991.

${ }^{7}$ A. Duro, "Togfjalëshat e qëndrueshëm terminologjikë në shqipen e sotme", SF, Nr. 4, 1982; H. Pasho, "Togfjalëshat e zgjeruar emërorë në terminologjinë e ekonomisë ",SF, nr. 4, 1985; L. Dodbiba, "Vërejtje rreth pastrimit të terminologjisë ", BUSHT, nr. 2, 1956; L. Dodbiba, "Leksiku i sotëm detar i shqipes dhe elemente të tij të pahuazuara", SF, Nr. 1, 1967; E. Çabej, "Elemente vendëse në terminologjinë gjeografike malore të gjuhës shqipe", SF, Nr. 3, 1979; F. Leka, "Për njësimin, pastrimin dhe pasurimin e mëtejshëm të terminologjisë tekniko-shkencore në gjuhën shqipe" "Probleme aktuale të kulturës së gjuhës shqipe”, Prishtinë , $1983 ;$ H. Pasho, "Fjala shqipe në terminologjinë e ekonomisë", "Studime filologjike dhe pedagogjike për nder të profesor Aleksandër Xhuvanit", Tiranë 1986; A. Duro, "Fjala shqipe në terminologjinë e mekanikës", SF, Nr. 4, $1988 ;$ A. Duro, "Probleme të shqipërimit të terminologjisë në kohën tonë ", SF, Nr.1-4, 1995; H. Pasho, "Fjalët e huaja në gjuhën letrare shqipe", SF, nr. 1-2, 1999; F. Leka, "Huazime dhe ndërkombëtarizma në terminologjinë teknikeshkencore" (botuar në "Shkrime gjuhësore, letrare, sociale", Tiranë, 2007; S. Titini, "Huazimet nga anglishtja në terminologjinë e së drejtës në gjuhën shqipe", "Seminari Ndërkombëtar për gjuhën letërsinë dhe kulturën
} shqiptare", Prishtinë, 2008. 
classification, the presence of notions without the relevant linguistic sign in the system of these notions and

b) a lack of coordination in the signs' system: the presence of multimeaning, synonimity and homonimity, phenomena which positively charactesise the general language, but negatively characterise the terminology. Obviously the solution to these problems depends to some extend on how deeply and widely this lexicon area has been studied. Basically these problems consist of the duties which arise from the necessities coming by the advance of science and technique, an advance which is accompanied with the appearance of many other notions, with the alteration of others which were previously created and the elimination of those notions which are considered old - fashioned.

As these terms are used because of immediate practical needs, the need for their systemation and equivalence is not very evident. Their use in school or scientific editions introduces scientists of various branches a problem which is linked to the terminology regulation and at the same time it attracts the attention of linguists who notice the inadequate borrowing of foreign words and the creation of terms - words in the wrong way. In this stage the terminology problem cannot be limited to its clearance of the unnecessary foreign words, but even its equivalence.

The development of the language terminology goes along with the social - economic and cultural development of the country where that language is spoken. Albania is a country which has historically known ancient civilizations, which has created lots of modern towns ans still continues to change the way of managing the territory by joining urban areas and by dividing the functions of inhabited areas according to a particular development policy. Despite the historical and political developments, the remains of civilization in the Albanian territory, ancient or modern, make us state that the urban area though not linguistically divided, has has its development in all times. Initially the documents that proved this development were in the form of sketches and drawings but Albania after the Liberation had a wide development and at that time, particular attention was paid to the opening of schools and different faculties at universities which aimed to increase the education level throughout the country. In 1969 we also have the opening of the architecture faculty near the construction faculty at the Politechnical University of Tirana. At that time we notice that the urban branch was part of the architecture branch and it was considered an independent subject. Later in 1984 we notice its separation from the architecture branch as a necessity for the creation of specialists who could undertake the detailing and updating of the first regulatory plans of towns, already composed by that time's Institute of projection ${ }^{8}$. The frequent contacts with the foreign world and the great insecurities about the towns' development made urban planning, as an independent branch, expand rapidly by so multiplying the written documents and the schoolbooks in this respect.

Work to coordinate urban planning terminology started exactly with the collection of the written documents for this branch. Part of these collected documents are: schoolbooks, magazines about actual problems, newspaper articles, laws of all times, administrative writings, materials of technical practices, etc.For each of the terms they created a file which contained the term in the linguistic form it was found, literature or literatures where it came from, the year when this literature was published, the number of the page and the row, and also a part of the context in which it was used. These files only have a descriptive character. The collection of terms was made considering the theories about the term which nowadays are numerous, but the criterion that guided the work of the Linguistic Institute in Albania about the publishing of many terminology dictionaries in various areas which has been mentioned above.

In terminology, more than everywhere in linguistics, the relation of its lexical system to the terminology system is evident, that is why the need for a close cooperation between the specialist and the linguist naturally arises. To establish the term we need a detailed analyses of the notion it expresses. According to the researchers Ferdinand Leka and Sifika Morcka9 the linguist without the

\footnotetext{
${ }^{8}$ Studimet e para te doktoratures ne kete fushen e urbanistikes jane miratuar vetem ne vitin 2009.

${ }^{9}$ F. Leka - S. Morcka, Zhvillimi dhe pasurimi i terminologjise pas clirimit, ne Studime mbi leksikun II, Tirane 1972.
} 
specialist of the respective branch risks to create terms which do not properly respond the content or create words which die prior to being properly born; on the other hand the specialist withouth the help of the linguist can unnecessarily adopt foreign words or Albanian words which have been "occupied" elsewhere and do not properly express the notion or do not meet the needs of the word - term. A similar collaboration is a necessity because the specialist of this branch waste too much time to understand terminology theories which make initial concepts for the linguist, whereas on the other hand it is impossible for the linguist to penetrate without the specialist's work in the inside of all those new scientific notions and the naming of the modern technique tools which is getting more complicated and specialised everyday. Based on this collaboration criterion, even the elaboration of urban terminology in the Albanian language compared to other languages, a commission has beeb set up, consisting of two urban specialists and two linguists one of whom has a long experience in practical work with terminology in Albania.

The collection of terms in a particular area is made by considering a system of related and dependant elements because providing the lexicon with systematic creations is more emphasizes in terminology because this is closely linked to the system of notions in the respective area. The terminology lexicon is distinguished because of its more systematic and more organised character compared to the non terminology lexicon. The study of the terminology lexicon as a system in accordance with the system of notions is reflected concretically for the fist time in the foreign linguistic literature in the works of $\mathrm{E}$. Wysterit ${ }^{10}$ and later on it is followed by a series of other researchers who have particularly worked on the terminology problems. The Albanian researchers ${ }^{11}$ have begun to consider terminology from its sytematic relations. Focusing on these systematic relations which we naturally find in the terminology of a well established area, we also act to collect the system of terms of the urban branch in Albanian language. Naturally after collecting all the written documents in Albanian, one- part terms have been put aside.They identify the branch and sub branch as well as they express the basic concepts. After that we have collected around them all the possible phrases ,thus identifying the absences in the system. This has also established the extend in number of the terms by setting boundaries in their extend towards the notions; detailing. Particular attention has been paid to the notions' detailing even because of the fact that in a terminology dictionary we should maintain a balance established in proportion to the number of terms that every sub branch will include.

As in the dictionary we intend to create, one of the criterion set from the very beginning has been the identification of the branch and the annexation of its basic concepts, in a first attempt in this respect, we have avoided the nomenclature making the selected terms be part of the dictionary and have an identity. As previously mentioned, this criterion is based on the Russian school of terminology which distinguishes terminology from nomenclature.

Prior to preparing the dictionary, each term is analysed in the circle of the microsystems of the respective branch and sub branch. The whole of these terminology microsystems make the respective branch itself where the terms cretare systematic relations. These relations serve to make each of the terms occupy the right position in the system, in accordance with the respective notion, whereas on the other hand, it broadens the opportunity to select the appropriate terms among the secondary ones, leaving aside the unsuitable ones. Unsuitability is clearly noticed when we have to select those terms which will be called interdisciplinary. As urban planning is very close to architecture, the basic notions are similar but the tendencies that they take and develop on their own are completely different. To illustrate this case we can use the term banese. This term belongs to architecture but the relations it creates are not the same for both branches. From an architect's point of view the word "banese" refers to the building where people live and its type, as it is

${ }^{10}$ E. Wüster, Internationale sprachnormung in der Technik, VDI, Berlin, 1931.

${ }^{11}$ F. Leka, Udhezues per perpunimin e terminologjise tekniko-shkencore, Tirane, 1983; H. Pasho, Zhvillimi $i$ terminologise se ekonomise, pas Clirimit dhe pasqyrimi i saj ne dy fjaloret shpjegues te gjuhes shqipe, "Studime filologjike", I, Tirane 1984; A. Duro, Togfjaleshat e qendrueshem terminologjike ne gjuhen shqipe, "Studime filologjike“, l, Tirane 1984. 
explained in today's Dictionary of the Albanian language ${ }^{12}$. In architecture we will also have phrases as banese me cardak, banese popullore, banese e tipit peristil, etc. Urban planning will enrich this word with groups of words which do not provide any longer the type of building but the way it is established in relation to the territory it possesses and in relation to other buildings which might offer it services such as educational, medical, commercial, etc. We do not find this relation to the territory in the above mentioned terms of architecture. In the urban planning we also have the phrases banese e vecuar, banesa te bashkengjitura, etc. The same happens with the term ndertese. In architecture we find terms such as: ndertese dyballore or ndertese industriale, which provide the kind of building or its function. Meanwhile in urban planning we have terms as: $\underline{n}$ dertesa te bashkengjitura, ndertesa te shperndara dhe ndertesa paralele, which show the way that these buildings are positioned in accordance with the territory. So as we can notice, although they are interdisciplinary terms, the phrases that we will select for each branch will be completely different.

This terminology practice based on the creation of a system of terms, helps even in case when we need to create more correct terms or to replace foreign terms which are not part of international terms because as we know, the scientific - technical terminology is the busiest part of the general lexicon with foreign terms and numerous terminology varieties.

\section{Terminology and General Literary Language}

In the elaboration of different terminologies for various branches of science and technique we have emphasized an important criterion with deals with exploiting the great opportunities that our language has for word - terms and the tendency that the development of our literal language has acquired in our times. ${ }^{13}$ We have considered this criterion even in the elaboration of the urban technology. Despite the new terms that have entered recently in thos area, we notice that urban planning is an area founded on the grounds of the Albanian language and has properly used it to create stable terminology phrases.The terminology lexicon used in today's dictionary of the Albanian language (1980) perfectly reflects this fact. This recent dictionary is an indicator of the rapid development of science and technique in our country in the period when this dictionary was published. Urban planning terminology, though unidentified with a relevant shortcut in the dictionary, is a consistent part of it. Knowing that this dictionary has reflected the real lexical structure of the Albanian language ${ }^{14}$ we will notice that in this reality the terminology of the urban planning is present in the comprehensive structure of more than 200 words of the general lexicon taken from this dictionary. The main principles which establish the constitution of words in a lexicographic work with a normative character act even on the principles of particular criterion to include or not include a part of the lexicon of technical - scientific terminology in this work. Theoritically "The Dictionary of today's Albanian language“ (1980) has started from the general principle that in it we should include technical - scientific terminology which has acquired general use, whereas the particularly special terminology used by a close circle of specialists, is not included in $\mathrm{it}^{15}$. The criterion of including a particular term in the "Dictionary" has mostly been its social role and not its importance in the system of notions of this or that branch of science or techniquei ${ }^{16}$.

We notice that along all the process of language development, there is a converse inclusion; on one hand passing the terms into the general lexicon and on the other hand, the words of this lexicon into terminology. Based on the observations made on the above mentioned dictionary to

\footnotetext{
${ }^{12}$ Sipas shpjegimit te dhene ne FGjSSH: BANESË f. - Ndërtesë ku banojnë njerëzit, shtëpi banimi. Banesa qytetare (fshatare, tiranase). Banesë e përbashkët. Ndërtimi (mirëmbajtja) e banesave. Hyj në një banesë të re. ${ }_{13}^{13}$ Fjalori i terminologjise tekniko-shkencore 1, Terminologjia e botanikes, Tirane 1963.

${ }^{14}$ Fjalor i gjuhes se sotme shqipe, Botim i Akademise se Shkencave te Shqiperise, Tirane, 1980.

${ }^{15}$ Th. Feka, Vezhgime mbi leksikun terminologjik ne "Fjalorin e gjuhes se sotme shqipe" (1980), ne Studime filologjike, Nr 2, 1986.

${ }^{16}$ A. Kostallari, Parimet themelore per hartimin e Fjalorit te gjuhes se sotme shqipe, ne Studime mbi leksikun dhe mbi formimin e fjaleve ne gjuhen shqipe, II, 1972.
} 
identify the urban planning branch, we distinguish that this interaction of terms and general lexicon has naturally occurred although as we previously mentioned, we do not find a shortcut of this branch in the dictionary. This fact indicates the widespread of the terminology use and its closure to the general lexicon. We notice this in those cases when the word appears with a terminology notion or is illustrated with terminology phrases since the very first meanings of the comprehensive structure. After that the development of new meanings can gain meanings which do not have a terminology character. This happens with the words taken from today's Dictionary of the Albanian language in whose meaning we have used italics and have underlined phrases which make terms of the urban planning:

ansambel m. - 2. Njësi, pjesë a sende të bashkuara në mënyrë të lidhur e të harmonishme në një tërësi të përbërë. Ansambël arkitektural. Ansambël ndërtesash.

hapesinor mb. - 1. Që ka të bëjë me hapësirën, që i përket hapësirës, i hapësirës. Kufiri hapësinor. ... . Pamje hapësinore. Shtrirje hapësinore.

kompleks m. - 1. Tërësia e elementeve përbërëse të diçkaje, që lidhen ngushtë ndërmjet tyre dhe plotësojnë njëri-tjetrin ${ }^{17} ; \ldots$.

kufizim m. - 2. Diçka që përcakton se deri ku e sa lejohet të veprojë dikush. Me shumë kufizime.

Pa asnjë kufizim ${ }^{18}$.

lagje f. 1. Pjesa e një qyteti ose e një fshati ... . Lagje e qytetit.

ndertese f. - Ngrehinë e madhe, që shërben për të banuar, si vend pune etj.; godinë. Ndërtesë shumëkatëshe. Ndërtesat shkollore. Ndërtesë banimi.

pallat $\mathrm{m}$. - 1. Ndërtesë e madhe me shumë kate, që shërben për banim, për zyra, për veprimtari kulturore, sportive etj. ... . Bllok pallatesh.

periferi f. 1. Pjesa që ndodhet në anë të një qendre të banuar, larg nga qendra e qytetit a e fshatit, lagjet e jashtme të një qyteti; pjesët anësore të një vendi, ... . Periferia e qytetit.

plan m. - 1. Lloj vizatimi që paraqet me anë vijash e shenjash të posaçme dhe në një shkallë shumë të zvogëluar një sipërfaqe të vogël toke, .... Plani i qytetit.

qytet m. - 1. Qendër e madhe banimi, me shumë shtëpi të ndara zakonisht në lagje, me rrugë e me sheshe të rregulluara, .... .

skeme f. - 1. Vizatim që paraqet në mënyrë të thjeshtësuar e pa hollësi vijat kryesore të diçkaje, ... ; plani sipas të cilit është ndërtuar diçka, duke e paraqitur në një vizatim me anë shenjash të posaçme ${ }^{19}$.

shesh $\mathrm{m}$. - 2. Vend i hapët në qytet a në fshat, zakonisht i rrethuar me ndërtesa, nga ku nisin disa rrugë kryesore; vend i rrafshët e i lirë pranë disa ndërtesash banimi ose në mes të tyre, .... Sheshi $i$ aytetit (i lagjes, i fshatit).

trull m. - 1. Copë toke, zakonisht e sheshtë, e caktuar për të ngritur një shtëpi a një ndërtesë, vend për ndërtim; pjesë toke që shënohet a që caktohet për rrugë, për sheshe sportive etj. vendi që zë një ndërtesë me pjesët dhe me sheshet e saj.

urbanistike f. - 1. Teoria dhe praktika e ndërtimit dhe e rregullimit të qyteteve sipas një plani të caktuar,... . 2. Sistemi i ndërtimit dhe i rregullimit të një qyteti: Urbanistika e qytetit.

urbanizoj kal. - 1. I jap një qendre të banuar tiparet e një qyteti, e kthej në qytet; rregulloj një qytet ose një qendër të banuar sipas një plani të caktuar për të krijuar kushte më të mira për jetesë e për punë.

vendbanim m. - Vendi ku banojnë njerëzit për një kohë të gjatë, fshati a qyteti ku dikush ka

\footnotetext{
17 Sipas A. Kostallarit, ne Parimet e kriteret themelore per zgjidhjen e problemeve te vecanta te Fjalorit te gjuhes se sotme shqipe, shprehet se per cdo fjale ose kuptim te nje fjale polisemantike do te perdoren nje ose dy shembuj ilustrues por, numri i citateve ilustruese mund te jete edhe me i madh kur egzistojne togje tipike fjalesh, te cilat duhet te jepen tek nje kuptim i caktuar, per ta bere te plote sqarimin e perdorimit te fjales ne kete kuptim. Duke u nisur nga kjo ne kete kuptim te pare te fjales, fare mire, do mund te shtonim, ne nje botim te ardhshem te fjalorit, togfjaleshin kompleks ndertimor, cka perben nje term te fushes se urbanistikes.

${ }^{18}$ Ketu do mund ta ilustronim kuptimin duke shtuar termin kufizim ne ndertim

${ }^{19}$ Do te mund te shtonim ne fjalor, sipas ketij kuptimi, termin skeme e qytetit.
} 
banesën e tij; qendër banimi. ...

These words - term we mentioned, though with no particular shortcut, either have on the dictionary first meanings of the urban planning, or in their first meanings are illustrated with examples of terminology phrases of this branch.

Always in the frame of collaboration of terms to general lexicon, many words from the general lexicon gain in their form even particular teminology meanings through specialising and usage in a particular science or technique branch ${ }^{20}$. In this case the term has or expresses the same meaning as the general lexicon word and helps to broaden the area of its usage. Considering the structure of polysemantic words in the dictionary and the internal variations of meanings, Androkli Kostallari writes: "In the polysemic words, which have long had many meanings, the further development of new meanings in many cases has been made in the line of each of the previous meanings ${ }^{21}$. In these cases the urban planning often stays beside other branches, thus helping to enrich the comprehensive structure of the general lexicon words. Jani Thomai claims that the new meanings of a word have arose one by one along the time. We notice that even nowadays at the comprehensive neologisms. The most characteristic example is terminology: apart from creating new terms, even words of the general lexicon are made into terms giving them a new meaning in this or that area of knowledge ${ }^{22}$. So we notice words which in their comprehensive structure have one or two special meanings which refer to the urban planning or that in these meanings are illustrated with phrases that express notions of urban planning which we have highlighted below in italics and underline. So:

faqe f. - 3. Secila nga anët e një sendi; sipërfaqja anësore e diçkaje; pjesa e përparme e kryesore e nië ndërtese, .... .

njesi f. - 4. Dyqan i veçantë ku shiten, grumbullohen a ndreqen sende të ndryshme. Njësi tregtare (ushqimore, industriale). Niësi shërbimi. ... .5. Ndarje gjeografike, administrative, ekonomike etj., që bën pjesë në një të tërë. Njësi gjeografike (territoriale).

mbyllur mb. - 7. Që është i ngushtë e i kufizuar në hapësirë; ... . Qytet (fshat) i mbyllur.

berthame f. - 3. fig. pjesa kryesore dhe më e rëndësishme, nga e cila zhvillohet diçka. ... . Bërthama e një qyteti.

bllok m. - 4. Grup ndërtesash, që shërbejnë për një qëllim ose që përbëjnë një tërësi me vete. Blloku i ndërtesave (i banesave, i shtëpive). ... 5. 5. Pjesë e një lagjeje në qytet, e përcaktuar si nënndarje e saj sidomos për veprimtarinë e organizatave shoqërore; .... .

unaze f. 7. Rrugë që kalon rreth e rreth qytetit ... . Unaza e qytetit.

pamje f. - 3. Pjesë e natyrës ose e vendit që shtrihet para syve; ajo që rroket nga vështrimi nga një pikë e caktuar. ... . Pamjet madhështore të maleve tona ${ }^{23} . .$. .

qender f. - 3. Pjesa e qytetit ose e fshatit, ku bashkohen rrugët kryesore dhe ku ndodhen ndërtesat kryesore shoqërore, shtetërore, kulturore etj. Qendra e qytetit (e fshatit)... .

zone f. - 4. Vend a truall i kufizuar, ku zhvillohet një veprimtari e caktuar ose ku ndodh diçka.

These words in general language as well as in terminology preserve their content by serving even the system of literature language and the terminology subsystem. Giving close terminology meanings to common language words is a frequent phenomena in today's Albanian language. As Ferdinand Leka ${ }^{24}$ states, in this way, not only the terminology systems are enriched, but in most cases the semantic structure of the word itself is broadened. As we noticed from the examples, the words of the general lexicon have sometimes acquired direct meanings of urban planning

${ }^{20}$ Th. Feka, Vezhgime mbi leksikun terminologjik ne "Fjalorin e gjuhes se sotme shqipe" (1980), ne Studime filologjike, Nr 2, 1986.

${ }^{21}$ A. Kostallari, Parimet themelore per hartimin e Fjalorit te gjuhes se sotme shqipe, ne Studime mbi leksikun dhe mbi formimin e fjaleve ne gjuhen shqipe, II, 1972.

${ }^{22} \mathrm{~J}$. Thomai, "Prejardhja semantike ne gjuhen shqipe“, Tirane, 1989.

${ }^{23} \mathrm{Ne}$ kete kuptim pamja percaktohet si pjese e natyres ose e vendit duke dhene vetem nje shembull per natyren nderkohe qe fare mire mund te shtonim termin pamje e qytetit per te ilustruar percaktimin si pjese e vendit.

${ }^{24}$ F. Leka, "Terminologjia tekniko-shkencore dhe gjuha e sotme letrare shqipe", SF, Tirane 1989, 3, f. 647. 
terminology and sometimes have increased the volume of information given to specify the word by bringing a considerable number of terminology phrases in this branch.

The terminology of urban planning also appears in a metaphorical meaning:

berthame f. - 3. fig. pjesa kryesore dhe më e rëndësishme, nga e cila zhvillohet diçka. ... . Bërthama e një qyteti.

In the general dictionary we encounter a category of words which come from books and have been signed in the dictionary with the abbrevation libr. A similar abbrevation in the dictionary is for the words korpus and forum which at the same time are urban planning terms and we find them in phrases use korpus ndertimor and forum romak. The fact that this category of terms has such an abbrevation shows the tendency of the dictionary to distinguish them as terms though not classified in a particular branch.

According to A. Kostallarit, the enrichment of today's Albanian lexicon is firstly made under the influence of the necessities for an exact terminology and the general requests to highlight the language culture ${ }^{25}$. The development of a particular terminology and the creation of the relevant terminology system, as the example of urban planning terminology, consequently brings even the development and enrichment of the content which is reflected in the definitions provided in an explanatory dictionary. Aswe know, the essential duty of an explanatory dictionary is to establish and explain the meaning or meanings of the word, when it is polysemantic. This motivates the urban planning terminology inclusion in a future dictionary of today's Albanian language considering the tendencies of the meanings' development. In the following examples we try to explain how this terminology brings meaning variations nowadays:

shfrytezim m. - 3. Shtie në punë diçka, e përdor për një qëllim të caktuar;... Shfrytëzojnë makinat (makineritë, pajisjet). Shfrytëzuan mbeturinat (rezervat e brendshme). Shfrytëzojnë hekurudhat (mjetet e transportit). Shfrytëzojnë burimet ekonomike (energjinë e lumenjve, energjinë diellore, energjinë atomike). Shfrytëzojnë ujin e lumenjve për ujitje. Shfrytëzoj librat (dokumentet, arkivat, literaturën, kartotekën). Shfrytëzon plotësisht kohën e punës. Shfrytëzon çdo minutë. As we notice, the concept of exploiting is given by using examples of mobile tools or materials. If we could add the urban planning term shfrytezim $i$ territorit, we would extend the meaning of the word to something immobile and not transportable.

i ngurte mb. - 3. fig. Që ngul këmbë në qëndrimin e vet a në bindjet e veta dhe nuk pranon të bëjë asnjë lëshim ose ndryshim sipas kushteve a rrethanave; që kërkon zbatim të rreptë pa asnjë shmangie ose ndryshim, i pandryshueshëm. Njeri i ngurtë. Qëndrim i ngurtë. Pikëpamje të ngurta. Normë e ngurtë. Metoda burokratike e të ngurta. We would bring concrete examples in this metaphorical meaning of the word, compared to the abstract examples provided for this worg, by adding in the dictionary skeme planimetrike e ngurte, and strukture e nqurte.

parim m. 3. Rregull themelor a ide drejtuese, sipas së cilës ndërtohet diçka. Parimi fonetik (morfologjik). gjuh. Parimi i ndërtimit të një makine. Here we would add the terminology phrase parime kompozicionale te urbanistikes thus providing an example of using the plural word and giving a help in enriching the uses of particular grammar categories of the noun.

amulli f. - Mungesë gjallërie, zhvillimi e përparimi, mbetje në vend (për ekonominë, punën, jetën mendore etj.); gjendje e fjetur. Amulli ekonomike. Amulli e përgjithshme. Amulli mendimi. Amulli në prodhim. Në gjendje amullie. Bie në amulli. Dal nga amullia. In the dictionary, the word is explained only with abstract examples meanwhile in the urban planning the term amulli e lagjes is widely used, which would illustrate the word more concretely.

bosht m. 7. fig. Drejtimi kryesor i një pune ose $i$ një veprimtarie; vija kryesore ideore e një vepre shkencore, letrare etj.; vija themelore rreth së cilës shtjellohet një veprim, një tok ngjarjesh etj. Boshti ideologjik. Boshti i punës. Boshti i dramës (i romanit). Boshti i ngjarjeve. This meaning becomes more concrete if we could add the term bosht kompozicional i qytetit.

The connotations of the meaning are more precise comprehension divisions, that's why terminology can help in their correct definition.

${ }^{25}$ A. Kostallari, Parimet themelore per hartimin e Fjalorit te gjuhes se sotme shqipe, ne Studime mbi leksikun dhe mbi formimin e fjaleve ne gjuhen shqipe, II, 1972. 
Terminology, as a subsystem of literature language, though it uses the same means and methods of wordformation which act in the general language, is characterised by particular characteristics in wordformation which are connected to the notable particularities of the term in relation to the word in the general language.

The difference in the formation of words in the general literature langiage and the terms in terminology is closely linked to the characteristics that a term should possess as a special nomination which is used in a particular branch.

The creation of terms is an aware linguistic activity which requests from the creator a careful work in using wordformation tools to make new terminology units which accurately provide the notion by distinguishing it from the similar notions within a certain branch.

The synthetic character as one of the main features of special communication, basically expresses the terminology lexicon's tendency to transmit as much information through economic means of speech. For this reason, during termformation we have prioritised the creation of new terms which clearly express notions in a particular branch through forms, from the expanding point of view, as short as possible. At the same time, during this process, particular importance was paid to the selection and combination of worformation elements so that the meaning of the term is understood from its external appearance or the nature of signs to be understood by the structure of the signaller.

The terms are signallers of different notions of an area. These notions constitute a system which is organised according to the degree of their complexity, thus influencing even in the creation of a similar system of terms which might be simple words expressing simple notions and not simple words ( derived, composed) or phrases which express derived notions.

In terminology the continuous formation of new terms is not explained with great wordformation abilities of the terminology system in relation to the general language system, but it is established by the rapid rhythm of development in different sections and the continuous reestablishment of existing terms and notions. ${ }^{26}$ Enriching the terminology of a branch with new terms is achieved in these ways:

a) The general language is the main source for the formation of new terms in the terminology of different branches of knowledge through the wordformation and semantic process.

Firstly a part of the terminology lexicon of a particular branch consists of new words created in morphological, morphological - syntactic and syntactic ways according to the degree of their production.

The formation of terms can be done by means of prefixes or suffixes which can be added to a word which serves as a productive topic, the alteration of its lexical - grammatical category, the unification of topics in compositions or the combination of words in phrases.

Secondly another part of the terminology lexicon is created through the process of terminologicalisation of general language words. These words of common usage, thanks to the alterations in their comprehensive structure, are specialised to nominate notions and characteristic phenomena of a branch by becoming part of the terminology system of that branch. Although they have come from the general language, the terms work as independent units compared to the word of the general language they originate from, and because of this reason they have new motphological and syntactical particularities. In this respect the terms and the words of general language they derive from, are united by a general idea created over the similarity of signallers while they are developed with their specific particularities within the respective systems. As a consequence, the word and the term create various synonimic and antonimic verses and respectively are : the word, a part of the lexical system of the general language and the term, a part of the terminology system in the respective branch. For eg: In urban planning we say rruget dalin nga qendra and to express its opposite we should use rruget hyine ne qender whereas we use rruget derdhen ne qender. Everyone may think that this use has emotional connotations going against the theories of the term which is considered with no such connotations. The use of the word

${ }^{26}$ M.Gotti, "I linguaggi specialistici caratteristiche linguistiche e criteri pragmatici” La nuova Italia, Firenze, 1991. 
derdhen in this terminology use does not express emotional connotation but a degree of intensity. So does the term strukture e lire, in urban planning terminology, it is not an antonym of strukture $e$ zene or e shtrenguar but of strukture e nqurte. The term sistem $i$ brendshem rrugor is not an antonym of sistem i jashtem rrugor but of sistem periferik rrugor. Ansambel urbanistik $i$ qete is not an antonym of ansambel urbanistik $i$ zhurmshem but it is an antonym of ansambel urbanistik dinamik.

b) The terminology of other branches is a source to complete the terminology lexicon of a particular branch with new terms. Frequently the terms which come from other branches preserve their initial meanings, but in some cases they acquire new meanings which are characteristic only of the branch where they enter into. "In general the interdisciplinary terms come to a certain branch from branches which have more elements in common with that or which they have very close relations with. This does not mean that in the terminology of a branch there do not enter terms from other very different branches". The passing of the term from the area of usage in a particular science into the area of usage in another science, undergoes the process of remeaning which is achieved in two ways:

Firstly when the initial terminology meaning is altered in a mening of general language and through riterminology it is used to nominate notions which belong to a new branch. In this way from the respective branches they pass onto urban planning terms such as siperfaqe, berthame, kompozim, arterie, etc.

Secondly when it is not the initial terminology meaning, but the metaphorical meaning which is transformed into the semantic nucleus of the new term which becomes part of the terminology system of another branch. So it has happened with terms like: amulli, ngulim, giurme, etc.

Borrowings from other languages make another source for terminology in various branches. Borrowings in terminology generally enter as a unity of meaningful words, though there are even cases when borrowings do not enter with the meaning they have in the language they come from, but another meaning. For eg: the word masterplan in the language where it was borrowed from has the meaning of a plan for an area with relatively big measures whereas in the Albanian language it has come with the meaning of a plan which establishes the position of the building with the territory.

Regarding the morphological way in the process of creating new terms, we notice that there are, as well as in other terminologies : a) not correctly created formations which nominate different notions from the ones used as a consequence of the careless use of any suffixes or the use of suffixes instead of one; b) formations which do not correspond to the wordformations of Albanian language, c) not common formations which may have a similar form in the past; etc.

In the grammar texts of the Albanian language as well as in the works of various researchers, where particularities and various problems about this way of wordformation are treated, we emphasize that the composition is one of the most productive ways after affixes which enrich the spoken and written language with new formations and which particularly are greatly expanding in the technical - scientific terminology. This is explained with the fact that, created by joining two motivating topics, the compositions carry a greater semantic importance compared to the deriving formations, by providing a clearer and more direct notion through a same economic form of speech $^{27}$. The composition is a productive way even in terminology, in general ${ }^{28}$, that's why we are mentioning some compositions which have a wide use in the urban planning terminology: rrethrrotullim, vendbanim, plan-organizim, planvendosje, projekt-ide, projekt-zbatim, qytet-kopesht, etc.

In the wordformation plan, we can generally say that in today's Albanian there dominates the clear tendency to fulfill new lexical needs in all areas with its tools of wordformation system. This

\footnotetext{
${ }^{27}$ A. Kostallari, "Kompozitat dëshirore e urdhërore", SF, Nr. 4, 1968; A. Xhuvani, Vepra I, Tiranë, 1980; Gramatika e gjuhës shqipe I, Tiranë, 1995.

${ }^{28} \mathrm{H}$. Pasho, "Terminologjia e ekonomisë në gjuhën shqipe nga Rilindja deri në vitet '80 të shekullit XX" (mbrojtur si disertacion në vitin 1986 dhe botuar në vitin 2005), Tiranë, 2005.
} 
makes an essential functional characteristic of wordformation of today's Albanian ${ }^{29}$. Urban planning, as one of the sciences which is mostly linked with the everyday life environments, follows the route of general lexicon development, but tends even from the general terminology development as well as from the specific particularities of its science mostly.

If we analyse the syntactic way of creating terms, we will undoubtedly stop on phrases. The development of various knowledge areas has led to the creation of a great number of new notions which cannot be nominated with just word- terms and as a result,term- phrases were created as a nominative lexical - syntactic unit which make a considerate amount of the terminology lexicon in the relevant branches. In the approach with the general language and the terminology lexicon, based on the opportunity of replacement or not of the consistent parts, we distinguish free phrases and terminologically stable phrases. The stable phrases have a fixed structure and work as an equal unit with the word which nominates different notions ${ }^{30}$.

The phrase has a structure which consists of two or more meaningful words. In this respect the phrases are simple, when they are created by joining two meaningful words, and broad phrases when they are created by joining a meaningful word with a simple phrase or by joining two phrases $^{31}$.In general, for the terminology phrase, there are ideas of specialists which do not treat them as terms, but as explanations and others which consider them as terms and justify why they are considered like that. In terminology, the broad terminological phrase has been fully thought as a term and it has been treated with the factual material of economy in a work about the terminology in this branch ${ }^{32}$. Treating terminology phrases has become an object of study even by lexicographs for the place they should in the explanatory dictionaries of the Albanian language and the problems related to their appearance in these dictionaries ${ }^{33}$.

The continuous discussions about the boundaries and the meaning of the broad phrase in terminology have established various attitudes. On one hand there are the supporters of the idea that these phrases represent difficulties during the use as terms because of the unification of a considerate number of components and that similar phrases may not be treated as terms as their meaning comes from the meaning of the components - term words and term phrases. On the other hand there are researchers that think that despite the great number of components joined in the phrase, which practically complicate its use as a term, from the meaning point of view every added component enables the exact expression of every new detail or feature of the notions nominated by them ${ }^{34}$.

Phrases have enriched the urban planning terminology with new nominations which accurately provide the content of the term through the features of the notion expressed by the component elements ${ }^{35}$. At the bases of the termformation process, apart from the clarity and accuracy criterion in expressing the notion, the selection of economic forms of expression that ease the term's use, is an important pragmatic criterion, thus the terndency for synthetisation is noticed in the phrases formation.

\footnotetext{
${ }^{29}$ A. Kostallari, Mbi tiparet kryesore te shqipes se sotme letrare, "Shkencat shoqerore ne shkolle", Nr.2, 1967.

${ }^{30}$ A. Kostallari në "Parimet themelore për hartimin e fjalorit të gjuhës së sotme shqipe" flet për lidhje të qëndrueshme me karakter terminologjik, kurse J. Thomai përmend në artikullin "Togfjalëshi, frazeologjia e fjala" disa togfjalësha me funksion të termave të pathjeshtë. Në artikullin "Togfjalëshat e qëndrueshëm terminologjikë në shqipen e sotme” A. Duro përdor termin togfjalësh terminologjik dhe trajton veçoritë që karakterizojnë këtë Iloj togfjalëshi.

${ }^{31}$ Gramatika e gjuhës shqipe II, Tiranë, 1997.

${ }^{32}$ H. Pasho, "Togfjalëshat e zgjeruar emërorë në terminologjinë e ekonomisë", SF, nr. 4, 1985.

${ }^{33} \mathrm{~V}$. Memisha Termat-togfjalësh në fjalorët shpjegues të shqipes, Konferencë shkencore Gjendja dhe zhvillimi $i$ terminologjisë shqipe probleme e detyra, Tiranë, 2009.

${ }^{34}$ A. Duro, Togfjalëshat e qëndrueshëm në terminologji në shqipen e sotme, SF, Nr.2, 1982; H. Pasho, "Togfjalëshat e zgjeruar emërorë në terminologjinë e ekonomisë", SF, Nr. 4, 1985; V. Memisha, Termattogfjalësh në fjalorët shpjegues të shqipes, Konferencë shkencore Gjendja dhe zhvillimi $i$ terminologjisë së shqipes, probleme e detyra, Tiranë, 2005.

${ }^{35}$ F. Scarpa, "Terminologia e lingue speciali", Manuale di Terminologia, Milano, 2002.
} 


\section{Conclusions}

Work with terminology in the Albanian language started in the '50s. As a result of this work, institutionally organised, about 33 dictionaries for 33 various knowledge areas were published. Following these lexicographic works there comes the work for the creation of a terminology dictionary in urban planning, as an independent branch. To create this dictionary they have followed the methods and principles of general terminology as well as the tendencies of the branch itself in particular. While working with the words, they have solved various semantic, morphological and syntactical problems aiming to elaborate the terms acoording to the Albanian language nature and thus greatly avoiding the use of those foreign terms which do not have the status of international terms.

\section{References}

A. Kostallari, "Parimet themelore per hartimin e Fjalorit te gjuhes se sotme shqipe", SF, Nr. 2, 1968.

F. Leka, "Terminologjia tekniko-shkencore dhe gjuha e sotme letrare shqipe", SF, Nr. 1, 1985;

H. Pasho "Terminologjia teknike-shkencore dhe vendi i saj në shqipen standarde" (botuar në përmbledhjen e punimeve të Konferencës" Shqipja standard dhe shoqëria shqiptare sot", Tiranë 2002.

H. Pasho, "Marëdhëniet e leksikut të përgjithshëm me terminologjinë" (botuar në përmbledhjen e punimeve të Konferencës "Gjuha letrare kombëtare dhe bota shqiptare sot", Tiranë, 2002.

K. Ashta, "Terminologjia dhe vëzhgimi i saj në leksikografinë e sotme" BSH i Institutit dyvjeçar të Shkodrës, nr. 9, 1970;

H. Pasho "Zhvillimi i terminologjisë së ekonomisë dhe pasqyrimi i saj në dy fjalorët shpjegues të gjuhës shqipe", SF, Nr. 1, 1984;

Th. Feka, "Vëzhgime mbi leksikun terminologjik në Fjalorin e gjuhës së sotme shqipe" (1980), SF, Nr. 2, 1986;

H. Pasho, "Leksiku terminologjik në veprën mësimore didaktike të Naim Frashërit", SF, Nr. 2, 1991;

F. Leka, "Vëzhgime gjuhësore dhe leksikografike mbi termat në Fjalorin e gjuhës së sotme shqipe" (1980) (botuar në "Shkrime gjuhësore, letrare, sociale", Tiranë, 2007.

H. Pasho, "Leksiku dialektor në terminologjinë teknike-shkencore në gjuhën shqipe", SF, Nr. 1-2, 1988; A. Duro, "Pasqyrimi i termave me strukturë togfjalëshi në fjalorët terminologjikë të shqipes" (Leksikografia shqipe trashëgimi dhe prespektivë ), Tiranë , 2005.

H. Pasho, "Vështrim mbi disa shfaqje të shumëkuptimësisë, sinonimisë dhe antonimisë në terminologjinë e ekonomisë në gjuhën shqipe", SF, Nr. 3, 1986; "Zhvillime kuptimore në terminologjinë e ekonomisë në gjuhën shqipe pas Çlirimit", SF, Nr. 2, 1988;

A. Duro, "Fjala term dhe struktura semantike e fjalës shqipe", SF, Nr. 3-4, 1991.

A. Duro, "Togfjalëshat e qëndrueshëm terminologjikë në shqipen e sotme", SF, Nr. 4, 1982;

H. Pasho, "Togfjalëshat e zgjeruar emërorë në terminologjinë e ekonomisë ",SF, nr. 4, 1985;

L. Dodbiba, "Vërejtje rreth pastrimit të terminologjisë", BUSHT, nr. 2, 1956;

L. Dodbiba, "Leksiku i sotëm detar i shqipes dhe elemente të tij të pahuazuara", SF, Nr. 1, 1967;

E. Çabej, "Elemente vendëse në terminologjinë gjeografike malore të gjuhës shqipe", SF, Nr. 3, 1979;

F. Leka, "Për njësimin, pastrimin dhe pasurimin e mëtejshëm të terminologjisë tekniko-shkencore në gjuhën shqipe" "Probleme aktuale të kulturës së gjuhës shqipe", Prishtinë , 1983;

H. Pasho, "Fjala shqipe në terminologjinë e ekonomisë", "Studime filologjike dhe pedagogjike për nder të profesor Aleksandër Xhuvanit", Tiranë 1986;

A. Duro, "Fjala shqipe në terminologjinë e mekanikës", SF, Nr. 4, 1988;

A. Duro, "Probleme të shqipërimit të terminologjisë në kohën tonë ", SF, Nr.1-4, 1995;

H. Pasho, "Fjalët e huaja në gjuhën letrare shqipe", SF, nr. 1-2, 1999;

F. Leka, "Huazime dhe ndërkombëtarizma në terminologjinë teknike-shkencore" (botuar në "Shkrime gjuhësore, letrare, sociale", Tiranë, 2007;

S. Titini, "Huazimet nga anglishtja në terminologjinë e së drejtës në gjuhën shqipe", "Seminari Ndërkombëtar për gjuhën letërsinë dhe kulturën shqiptare", Prishtinë, 2008.

F. Leka - S. Morcka, Zhvillimi dhe pasurimi i terminologjise pas clirimit, ne Studime mbi leksikun II, Tirane 1972.

E. Wüster, Internationale sprachnormung in der Technik, VDI, Berlin, 1931.

F. Leka, Udhezues per perpunimin e terminologjise tekniko-shkencore, Tirane, 1983;

$\mathrm{H}$. Pasho, Zhvillimi i terminologise se ekonomise, pas Clirimit dhe pasqyrimi $\mathrm{i}$ saj ne dy fjaloret shpjegues te gjuhes shqipe, "Studime filologjike", I, Tirane 1984;

A. Duro, Togfjaleshat e qendrueshem terminologjike ne gjuhen shqipe, "Studime filologjike", I, Tirane 1984.

Fjalori i terminologjise tekniko-shkencore 1, Terminologjia e botanikes, Tirane 1963.

Fjalor i gjuhes se sotme shqipe, Botim i Akademise se Shkencave te Shqiperise, Tirane, 1980. 
Th. Feka, Vezhgime mbi leksikun terminologjik ne "Fjalorin e gjuhes se sotme shqipe" (1980), ne Studime filologjike, $\mathrm{Nr}$ 2, 1986.

A. Kostallari, Parimet themelore per hartimin e Fjalorit te gjuhes se sotme shqipe, ne Studime mbi leksikun dhe mbi formimin e fjaleve ne gjuhen shqipe, II, 1972.

Th. Feka, Vezhgime mbi leksikun terminologjik ne "Fjalorin e gjuhes se sotme shqipe" (1980), ne Studime filologjike, Nr 2, 1986.

J. Thomai, "Prejardhja semantike ne gjuhen shqipe", Tirane, 1989.

F. Leka, "Terminologjia tekniko-shkencore dhe gjuha e sotme letrare shqipe", SF, Tirane 1989, 3, f. 647.

M.Gotti, "I linguaggi specialistici caratteristiche linguistiche e criteri pragmatici" La nuova Italia, Firenze, 1991.

A. Kostallari, "Kompozitat dëshirore e urdhërore", SF, Nr. 4, 1968; A. Xhuvani, Vepra I, Tiranë, 1980; Gramatika e gjuhës shqipe I, Tiranë, 1995.

H. Pasho, "Terminologjia e ekonomisë në gjuhën shqipe nga Rilindja deri në vitet ' 80 të shekullit XX" (mbrojtur si disertacion në vitin 1986 dhe botuar në vitin 2005),Tiranë, 2005.

A. Kostallari, Mbi tiparet kryesore te shqipes se sotme letrare, "Shkencat shoqerore ne shkolle", Nr.2, 1967.

Gramatika e gjuhës shqipe II, Tiranë, 1997.

H. Pasho, "Togfjalëshat e zgjeruar emërorë në terminologjinë e ekonomisë", SF, nr. 4, 1985.

V. Memisha Termat-togfjalësh në fjalorët shpjegues të shqipes, Konferencë shkencore Gjendja dhe zhvillimi i terminologjisë shqipe probleme e detyra, Tiranë, 2009.

A. Duro, Togfjalëshat e qëndrueshëm në terminologji në shqipen e sotme, SF, Nr.2, 1982; H. Pasho, "Togfjalëshat e zgjeruar emërorë në terminologjinë e ekonomisë", SF, Nr. 4, 1985;

V. Memisha, Termat-togfjalësh në fjalorët shpjegues të shqipes, Konferencë shkencore Gjendja dhe zhvillimi i terminologjisë së shqipes, probleme e detyra, Tiranë, 2005.

F. Scarpa, "Terminologia e lingue speciali", Manuale di Terminologia, Milano, 2002. 